\title{
Statyba
}

\section{A NEW RETARDING AGENT OF BUILDING GYPSUM HARDENING}

\author{
A. Kazragis , G. Marčiukaitis \& G. Jurkènas
}

To cite this article: A. Kazragis , G. Marčiukaitis \& G. Jurkènas (1996) A NEW

RETARDING AGENT OF BUILDING GYPSUM HARDENING, Statyba, 2:7, 30-32, DOI:

10.1080/13921525.1996.10531652

To link to this article: https://doi.org/10.1080/13921525.1996.10531652

曲 Published online: 26 Jul 2012.

Submit your article to this journal

III Article views: 84 


\title{
NAUJAS STATYBINIO GIPSO KIETĖJIMO LE'TIKLIS
}

\author{
A.Kazragis, G.Marčiukaitis, G.Jurkènas
}

\section{Iradas}

Statybinio gipso skiediniai pasižymi nedidele rišimosi ir kietėjimo proceso trukme: sumaišytas su vandeniu, jis po 4-15 min pradeda rištis ir kietèti. Todèl statybos ir remonto darbuose ji tenka naudoti skubiai, dažnai - nukenčiant darbo kokybei, o pati statybini gipsą, ypač remonto darbuose, tenka imti nedideliais kiekiais, kad sumaixius su vandeniu jis nesuspèty sukietèti dar nepanaudotas.

Statybinio gipso rišimosi ir kietèjimo procesui sulètinti nuo seno naudojamos ivairios medžiagos stalių, kaišu bei kazeininiai klijai, spyglių nuoviras, sulfitinio spirito žlaugtai, kalkių tešla, kalkių-kliju emulsija, taip pat kalio ir natrio fosfatai bei boratai, koncentruotas natrio chlorido tirpalas (praskiestas tirpalas procesą pagreitina) ir karštas vanduo.

Išvardintų medžiagų panaudojimas turi daug trūkumų: 1) ilga paruošimo (brinkinimo, virinimo, filtravimo) trukmé bei receptūros neapibrěžtumas (klijai, spygliu nuoviras, žlaugtai, kalkių-kliju emulsija), 2) gipso - priedų mišinių išsisluoksniavimas bei sukietèjusio gipso mechaninio atsparumo sumažèjimas (kalkių tešla, fosfatai ir boratai), 3) proceso komplikavimas vandens kaitinimu bei priedy poveikio neapibrèžtumu, nesant galimybès išlaikyti pastovią mišinio temperatūrą (karštas vanduo).

\section{Naujų gipso kietėjimo lètikliụ parinkimas}

Gipso kietėjimo lètikliais gali būti panaudotos medžiagos, sudarančios intarpinius junginius. Intarpiniais junginiais vadinamos medžiagos, susidarančios vienoms molekulėms jisiterpus i kitỵ molekuliy

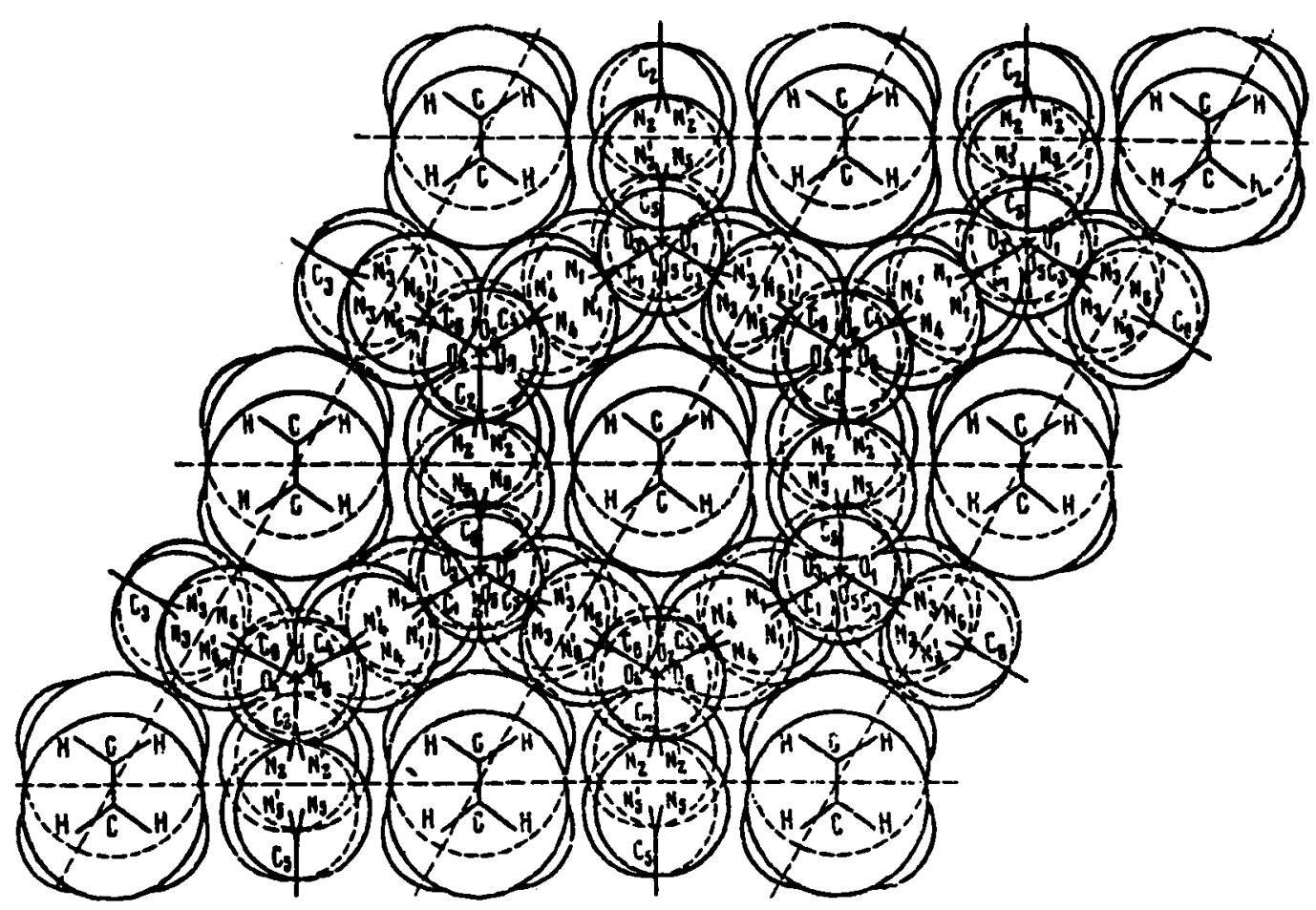

1 pav. Karbamido "kanalinio" ịterpimo junginio struktūros schema

Fig. 1. The scheme of the structure of "canalic" clathrate compound of carbamide 
tuštumas - kanalus arba narvelius. Tuštumų dydžiai tokiose medžiagose sudaro $0,3+3,0 \mathrm{~nm}(3+30 \stackrel{0}{\mathrm{~A}})$. Žinoma, intarpiniai junginiai gali susidaryti tik tada, kai vienų medžiagų molekulèse esančių tuštumų gabaritai yra artimi "įstringančių" molekuliu gabaritams.

Viena is populiariausių intarpinius junginius sudarančių medžiagu yra karbamidas $\mathrm{CO}\left(\mathrm{NH}_{2}\right)_{2}$. Karbamidas sudaro II singonijos kristalinę gardelę. Jos parametrai: $a=5,67 ; c=4,72 \stackrel{\circ}{A}$. Karbamido kristalinèje gardelèje esančį tuštumy schema parodyta 1 pav., paimtame iš [1].

Yra žinoma [2], jog karbamidas su kalcio sulfatu $\mathrm{CaSO}_{4}$ sudaro jungini $\mathrm{CO}\left(\mathrm{NH}_{2}\right)_{2} \cdot \mathrm{CaSO}_{4} \cdot \mathrm{H}_{2} \mathrm{O}$.

Gipsas - kalcio sulfato dihidratas $\mathrm{CaSO}_{4} \cdot \mathrm{H}_{2} \mathrm{O}$ - sudaro V singonijos, monoklininès sluoksniuotos struktūros, kristalinę gardelę, kurios schema parodyta 2 pav., paimtame is [3]. Kaip matome, gardelèje pakaitomis eina vandens molekuliu ir kalcio bei sulfato jonų sluoksniai. Gipso kristalinè gardelè turi tokius parametrus: $a=10,47 ; b=15,15 ; c=6,51 \stackrel{\circ}{A}$. I $\mathrm{CaSO}_{4}$ sudètị jeinantys jonai turi łiuos skersmenis: $\mathrm{Ca}^{2+} 2,08 ; \mathrm{SO}_{4}^{2-} 4,6 \stackrel{\circ}{\AA}$.

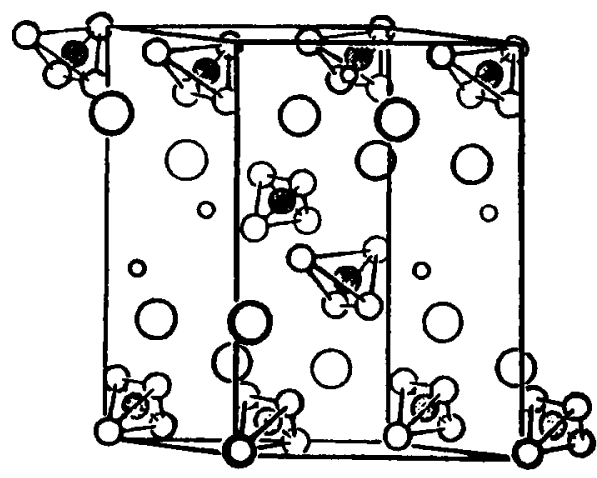

2 pav. Kalcio sulfato dihidrato kristalinès gardelès schema

Fig. 2. The scheme of crystal lattice of the calcium sulphate dihydrate

Statybinis gipsas - kalcio sulfato pushidratis $\mathrm{CaSO}_{4} \cdot 0,5 \mathrm{H}_{2} \mathrm{O}$, užmaił̌ytas vandeniu, sudaro dihidratą - "gipso akmenị":

$$
\mathrm{CaSO}_{4} \cdot 0,5 \mathrm{H}_{2} \mathrm{O}+1,5 \mathrm{H}_{2} \mathrm{O}=\mathrm{CaSO}_{4} \cdot 2 \mathrm{H}_{2} \mathrm{O} .
$$

Kai sistemoje yra karbamido, dalies "gipso akmens" susidarymas vyksta karbamido kristalinès gardelès kanaluose. Dèl to "gipso akmens" susidarymo greitis, esant misinyje karbamido, sulètèja. Taigi karbamidas gali būti panaudotas kaip statybinio gipso kietẻjimo lètiklis.
Mūsų atlikti eksperimentai patvirtino aukš̉iau išdèstytus teorinius samprotavimus. Todèl kaip darbo rezultatas buvo sukurtas naujas statybinio gipso kietèjimo lètiklis, kurio veikimas remiasi intarpinio junginio susidarymu. Rekomenduojamą lètikli sudaro du komponentai: 1) Jonavos $\mathrm{AB}$ "Achema" gamybos karbamidas, 2) proceso greiti stabilizuojantis neorganinis priedas. Karbamido ir priedo masiu santykis kompozicijoje sudaro 40:1. Abu komponentai lètina gipso kietèjimo procesą, tačiau esant mažesniam komponenty masių santykiui, mišinys išsisluoksniuoja, o esant didesniam - sumažèja mechaninis sukietèjusio produkto atsparumas. Lètiklis lengvai tirpsta $10-20^{\circ} \mathrm{C}$ temperatūros vandenyje. Naudojant ši lètikli, statybinio gipso kietèjimo trukmè gali būti pratęsta iki $90 \mathrm{~min}$.

Pagrindiniai létiklio panaudojimo esmę apibūdinantys požymiai yra క̌ie: 1) priedo kiekis tesudaro 4\% sauso statybinio gipso masès, 2) statybinio gipso skiedinio, i kuri idèta lètiklio, kietèjimo trukmè gali būti pailginta iki $90 \mathrm{~min}$, 3) statybinio gipso skiedinys, turintis lètintojo, panaudojimo metu neišsisluoksniuoja, 4) lètiklio įdèjimas $\mathfrak{i}$ statybinio gipso skiedinį nesumažina sukietèjusio produkto mechaninio atsparumo, 5) ịdedant lètiklị gali būti naudojamas statybinis gipsas, gautas is fosfogipso.

Rekomenduojamas statybinio gipso kietėjimo lètiklis gali būti panaudotas statybos ir remonto darbuose, taip pat gaminant gipsbetonio panelius bei kitus dirbinius pramoniniu būdu. Lètiklis gali būti naudojamas apdailos plyteliy siūlèms užpildyti patalpose, kurių oro drègnumas ne didesnis kaip $75 \%$.

\section{IǏvados}

Statybinio gipso riß̌mosi ir kietèjimo procesui sulètinti naudojami lètikliai, kurie:

a) mažina pushidračio gipso tirpumą (amoniakas),

b) sudaro jo grūdelių paviršiuje sunkiau tirpstančius junginius (natrio ir kalio fosfatai, tetraboratas, boro rūgštis),

c) adsorbuojasi gipso grūdeliu paviršiuje ir trukdo susidaryti kristalų užuomazgoms (sulfitinio spirito rangas, keratinas).

Minètos medžiagos turi trūkumų: 
a) ilga paruošimo (brinkinimo, virinimo, filtravimo) trukmè bei receptūros neapibréžtumas (klijų tirpalai),

b) gipso ir priedu mišiniu išsisluoksniavimas bei sukietejjusio gipso mechaninio atsparumo sumažèjimas (fosfatai, boratai),

c) proceso komplikavimas vandens kaitinimu bei priedų poveikio neapibréžtumu, nesant galimybès išlaikyti pastovią mišinio temperatūrą (karšrtas vanduo).

Sukurtas naujas statybinio gipso kietėjimo lètiklis, neturintis išvardintų trūkumų, kurio veikimas remiasi intarpinio junginio susidarymu. Lètikli sudaro karbamidas ir neorganinis stabilizuojantis priedas, paimti santykiu 40:1. Statybinio gipso skiedinio, i kuri ¡̇dèta rekomenduojamo lètiklio, kietėjimo trukmè gali būti pailginta iki $90 \mathrm{~min}$.

\section{Literatūra}

1. А.И.Китайгородский. Органическая кристаллохимия. М.: Изд-во АН СССР, 1955. 534 с.

2. Краткая химическая энциклопедия. Т.3. М.: Сов. энциклопедия, 1964. 328 с.

3. Б.Ф.Ормонт. Структуры неорганических веществ. М.-Л.: Гос.изд. техн.-теорет. лит., 1950. $780 \mathrm{c}$

\section{Iteikta 19960315}

\section{A NEW RETARDING AGENT OF BUILDING GYPSUM HARDENING}

\section{A.Kazragis, G.Marčiukaitis, G.Jurkẻnas}

\section{S u m m a r y}

In order to inhibit the process of setting and hardening of building gypsum, retarding agents are used. They:

i) decrease the solubility of gypsum semihydrate (e.g. ammonia),

ii) form compounds of lower solubility on the surface of gypsum grains (sodium and potassium phosphates, tetraborate, boric acid),

iii) are absorbed on gypsum grain surface and inhibit the formation of crystal nuclei (sulphite alcohol ferment, keratin).

The materials mentioned above have some disadvantages: i) long duration of preparation (lying, boiling, filtering) and uncertainty of formulae (glue solutions),

ii) layering of gypsum additions mixtures and decrease of mechanical resistance of hardened gypsum (phosphates, borates),

iii) process complications caused by necessity of water heating that leads to uncertain influence of additions when the conditions for maintaining constant temperature of the mixture are absent (hot running water).

New retarding agent, inhibiting the hardening of building gypsum without disadvantages listed above is created. The effect of the retarding agent is caused by the formation of clathrate compounds. The retarding agent consists of carbamide and inorganic stabilising addition, in ratio $40: 1$. The duration of the complete hardening of building gypsum can be prolonged by the retarding agent up to $90 \mathrm{~min}$.

Algimantas KAZRAGiS. Doctor Habil, Professor. Head of the Department of Building Materials and Chemistry. Vilnius Gediminas Technical University (VGTU), 11 Saulètekio Ave, 2040 Vilnius, Lithuania.

Doctor Habil of natural sciences (Chemistry), Lithuanian Academy of Sciences, 1990. Professor (1993) Teaching: lectures on six branches of chemistry and building materials. Author of 5 textbooks, 130 scientific articles. Research interests: thermodynamics and kinetics of inorganic and building materials.

Gintaras JURKE்NAS. Head of Laboratory of Reinforced Concrete Structures. Vilnius Gediminas Technical University, 11 Sauleetekio Ave, 2040 Vilnius, Lithuania.

A graduate of Vilnius Civil Engineering Institute (now VGTU, 1983, civil engineer). He has finished his PhD course. Author of several research papers and reports at conferences in Lithuania and abroad. Research interests: composite structures and materials, renovation of structures.

Gediminas MARČ́IUKaTTIS. Doctor Habil, Professor. Department of Reinforced Concrete Structures at Vilnius Gediminas Technical University, 11 Saulètekio Ave, 2040 Vilnius, Lithuania.

A graduate of Civil Engineering Faculty of Kaunas Polytechnical Institute in 1957. Ph D in 1963. Research at the University of Illinois in 1969. Doctor's Habil degree in 1980 at Moscow Civil Engineering Institute. Professor (1982). Author and co-author of 4 monographs, 2 textbooks and more than 230 scientic articles. Research interests: mechanics of reinforced concrete, new composite materials and structures, renovation of buildings. 